\title{
FAMILY MEMORIES: \\ INVENTING ALFONSO I OF ASTURIAS
}

\author{
Julio Escalona \\ Instituto de Historia, CSIC
}

Most of what present day historians can say about the earlier phases in the development of the kingdom of Asturias derives from a handful of historical texts composed during the reign of Alfonso III (866-910): the two versions of the Chronicle of Alfonso III and the socalled Prophetic Chronicle and Chronicle of Albelda. ${ }^{1}$ All earlier sources are very few and scattered, until these substantial works suddenly cast light on the period from the Arab invasion to the end of the ninth century. In the absence of comparable earlier evidence, historians have largely tended to take these chronicles at face value when approaching the otherwise intractable subject of the origins of the Asturian kingdom, despite their being almost two hundred years later than the 711 Arab invasion of Spain. This, though, is a great problem, since these texts are much less innocent than they look. For all their efforts in drawing a straight line connecting the Visigoths to the Asturians, the late ninth-century chronicles are - it is now recognised - the first coherent expression of a total u-turn in Asturian political identity, that took shape by the mid-ninth century, but did not make its way into historical writing until the 880s.

To analyse this thoroughly is well beyond my present concerns. I will instead, focus on one single element, namely, the way the ninthcentury chronicles deal with the figure of King Alfonso I. Now, can this possibly be of any relevance? The answer, I think, must be affirmative, if only because the chroniclers at least seem to have attached great significance to him. Let us take, by way of introduction, a rough quantitative approach. Fig. 1 represents the number of words employed when describing the reigns of the Asturian eighthcentury kings by two of the main texts to which I will refer later.

${ }^{1}$ Chronicle of Alfonso III and Albeldensis, ed. and Spanish trans. Gil (1985); Prophetic Chronicle, ed. Gómez-Moreno (1932) 622-627. An English translation of the Rotensis version of the Chronicle of Alfonso III in Wolf (1990) $159 \mathrm{ff}$. 


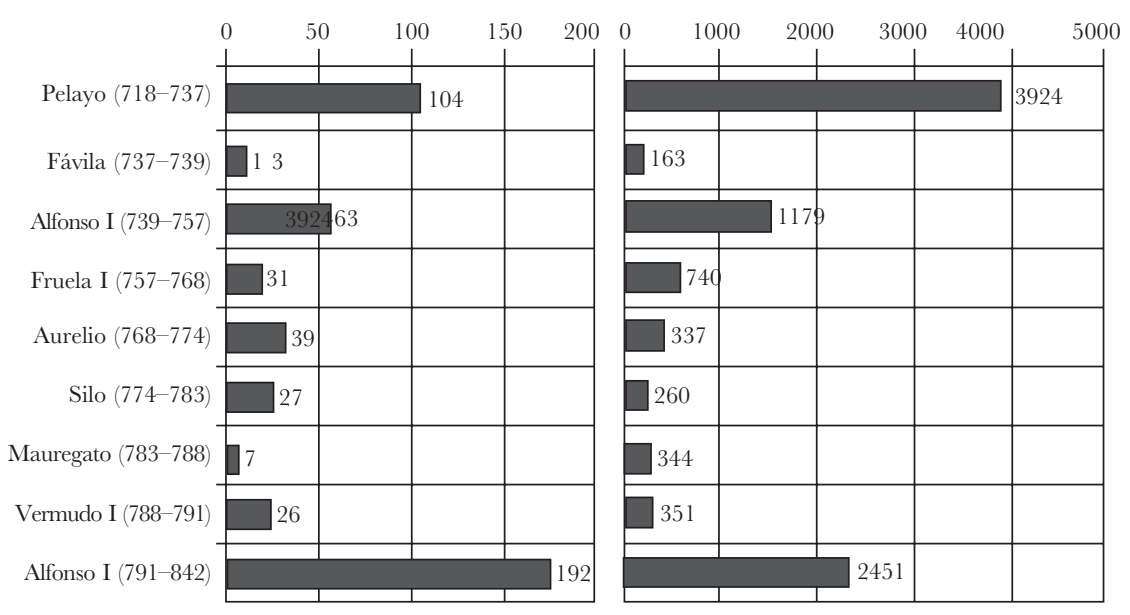

Fig. 1: Number of words used for describing the reigns of each of the eighthcentury Asturian kings in the Albeldensis (left) and Ovetensis (right).

Rough as the method is, it is enough to reveal the basic facts: although the Chronicle of Alfonso III is much more detailed than the Albeldensis, the pattern is the same. Three kings clearly stand out. On the one hand, it is little wonder that Pelagius should have attracted so much attention, for he was considered the founder of the Asturian kingdom. On the other hand, Alfonso II's unusually long reign really needed a more detailed account, and also because important political developments took place then. But, what happened in between? Amidst six rather obscure figures, Alfonso I is the single outstanding landmark, an impression which is further reinforced by noticing that these three kings - Pelagius, Alfonso I and Alfonso II - are the only eighth-century rulers to whom any miracles are ascribed in the royal chronicle.

Clearly, for the late ninth-century chroniclers Alfonso I was a prominent character of their earlier history. My point, though, is that Alfonso I's function in the ninth-century chronicles was more than just that of a prestigious ancestor. Whichever his real deeds, he can be seen as a largely made-up, taylor-cut figure. This is certainly worth investigating. In the following pages, I shall first present the main primary sources and then briefly discuss the more relevant steps in the ninth-century development of an Asturian political identity moulded from visions of their eighth-century history. This will 
provide the background for analysing the role of Alfonso I in the late ninth-century chronicles, which I will discuss at length. In doing so, I hope that many of the intricacies in the chroniclers' discourse and procedures will become apparent.

\section{Changing Political Identities in Early Medieval Asturias}

\section{The Source Material}

The Chronicle of Alfonso III was written at the royal see of Oviedo with the main purpose of showing the Asturian kings as the natural heirs to the Visigoths. The work explicitly presents itself as a continuation to Isidore's Chronicle, running from Reccesvinth's accession (649) down to the death of Alfonso III's father, Ordoño I (866). ${ }^{2}$ Two different versions of the chronicle are known: the so-called Rotensis and Ovetensis (or Ad Sebastianum). Against the long admitted view that Ovetensis was a later, more refined revision of Rotensis, it seems now well-established that they both derive from an earlier, lost archtype, ${ }^{3}$ to which the Rotensis adheres to a great extent. The Ovetensis, on the other hand, carefully inspected and modified its source, by making a number of major changes and filtering the wording throughout the text. In doing so, its author or authors created a more strongly coherent text in support of what can be considered the late ninth-century Asturian 'official' truth about their history.

The so-called Chronicle of Albelda or Albeldensis was written in Oviedo around 882. It clearly belongs in the ideological milieu of Alfonso III's court, and it certainly dwells upon many issues which were also the focus of the royal chroniclers, but the Albeldensis is a peculiar work that mixes up, very un-systematically, different kinds of information: linguistic, geographic and historical, among others. Since it does not seem to have been 'monitored' as strictly as the royal chronicles were, there are many elements in it that differ from the more

${ }^{2}$ Gil (1985) $74 \mathrm{ff}$. convincingly argued that the original text could well run only to Ordoño I's early years, and have been continued later on, under Alfonso III.

${ }^{3}$ Prelog (1980) lxxx ff.; Gil (1985) 60 ff. 
'official' texts. Therefore, it makes a good contrast to the Rotensis and Ovetensis. ${ }^{4}$

\section{The Period of Carolingian Infuence}

Before proceeding with Alfonso I, it will be convenient to briefly review how a historical identity emerged in the early Asturian kingdom. The first decades in the history of the Asturian kingdom - the crucial phase in which the new polity came into being - are disappointingly obscure. Because most of our information derives from the ninth-century chronicles, modern visions of this period are often dominated by an image of great continuity with the Visigothic past, which is precisely what the chroniclers wanted to stress. Yet, for all that Alfonso III's courtiers would have us believe, such an inheritance would hardly satisfy the late eighth- and early ninth-century Asturian kings, who rather saw themselves as radically different from the Visigoths.

After the 711 Arab invasion of Spain, and the subsequent collapse of the Visigothic kingdom, there is hardly any contemporary trace of an Asturian monarchy before the 760s. If Pelagius's alleged victory at Covadonga ever occurred, it made no impact in sources of its time, such as the so-called Mozarabic Chronicle of 754; references to that episode in Arabic texts are themselves later than, and arguably dependent on the ninth-century Asturian chronicles. Instead, the impression is growing ever stronger that the first half of the eighth century was dominated by a multifocal pattern of power. Rather than a single expanding monarchy, several aristocratic kindreds competed for hegemony from a number of territorial centres which would eventually turn into royal sees inasmuch as the local ruler achieved kingship. ${ }^{5}$ It was only from hindsight that such a complex magma was shaped into a single kingship and a linear - if somewhat erraticdynastic succession.

We must wait until the reigns of kings Silo (774-783) and Mauregato (783-788), to find the first traces of substantial political developments

\footnotetext{
${ }^{4}$ See Gil, (1985) 81 ff.; Díaz y Díaz (1983) 228-232, conjectured it could have been written at San Salvador de Oviedo, as its library collection would account for the author's sources.

5 Torrente (1997); Suárez (2002); Estepa (2002).
} 
in the Asturian regions. It seems now ever clearer that this was not only due to internal transformations, but also to the increasing Carolingian influence. After the subjection of Septimania in 750, the Carolingians grew ever more active in northern Iberia in the second half of the eighth century, with even greater intensity in the period 770-800, following the establishing of the Ummayad dynasty, which put an end to serious internal struggles in al-Andalus. ${ }^{6}$ The milestones of the uneven Carolingian progress on Iberia's eastern side are well known, from the ill-fated 778 expedition to Saragossa to the 801 conquest of Barcelona. Pamplona, the main stronghold in the Basque area, seems to have entered the Frankish sphere of influence, perhaps following a continued trend from the sixth century, as recent archaeological findings seem to indicate. ${ }^{7}$ What happened further west, though, is not so well established. The available evidence suggests that the neighbouring polities, such as Álava, might have undergone some sort of informal domination, as satellites of the Franks. As for Asturias, the Carolingian factor has been long underestimated, partly because it was systematically denied by the ninthcentury chroniclers. Yet, some independent bits of evidence from Frankish sources make rather clear that in the critical 790s King Alfonso II of Asturias was on more than good terms with Charlemagne, of whom he was no peer. ${ }^{8}$ That was a crucial factor in the political growth of the Asturian monarchy under Alfonso II, as recent research reveals the great extent to which the Asturian contemporary political culture and ideology depended on Carolingian models. ${ }^{9}$

Although those Frankish references belong to the 790s, the whole process may well have started earlier. The evidence for this is much more difficult to deal with, but detailed analysis of the Asturian ecclesiastical sources has led A. Isla to suggest that as early as the reign of Mauregato (783-788), a growing proportion of the Asturian clergy were assuming the main themes of the Carolingian religious culture,

\footnotetext{
${ }^{6}$ By 776 Abd al-Rahman I had overcome rebels and resistants and was finally free to act against external powers; see Collins (1989), 170 ff.; Collins (1998), 66.

${ }^{7}$ Larrañaga (1993); Azkárate (1993).

${ }^{8}$ The Royal Frankish Annals, s. a. 798, and the Annales Laurissenses, s. a. 798 mention Asturian legates and presents being sent to Charlemagne. Einhard is somewhat more explicit in stating that Alfonso II had great pleasure in being called Charlemagne's own man (Vita Karoli, II, 16), ed. Holder-Egger (1907), English trans. Thorpe (1969). See Fernández Conde (1997).

${ }^{9}$ Fernández Conde (1997); Isla (1998a).
} 
even if building on a basically Hispanic, post-Visigothic background. ${ }^{10}$ Texts such as Beatus of Liébana's famous Commentary on the Apocalipse ${ }^{11}$ or the Hymn - also often attributed to Beatus - O Dei Verbum in praise of St. James, but comprising an acrostic dedication to King Mauregato, are pieces in this renewed ideology that ultimately led the adoptionism controversy to burst out. ${ }^{12}$ Adoptionism was instrumental in delivering a lethal blow to what little was left of a Spanish Church that had thitherto struggled to keep some notion of cross-Iberian unity and authority, even if under Muslim rule. I cannot deal here at length with the whole subject: ${ }^{13}$ for my present interests, it will suffice to consider its wider implications in two different contexts: on the one hand, the global background of rising Carolingian hegemony within the Latin Christendom; on the other hand, the small scale process going on in Asturias, under the cover of the more general, large scale developments.

On the larger scale, the Carolingians took deep involvement in the adoptionism controversy. Hence the participation of relevant intellectual figures such as Alcuin or Benedict of Aniane, the sending of envoys such as Jonah of Orleans, the formal condemnation in Regensburg (792) ${ }^{14}$ and in the council of Frankfurt (794) ${ }^{15}$ as well as the prosecution of those adoptionists who where at the easiest reach, such as Felix of Urgel. The ultimate defeat of the Visigothic traditional doctrines defended by none other than Archbishop Elipandus of Toledo, the customary head of the Spanish Church, fuelled the claims of those who had decided to take a non-conformist stand towards their Muslim rulers, and who can be seen as the remote forerunners of the mid ninth-century martyrs of Córdoba. ${ }^{16}$ More importantly, it broke into pieces whatever legitimacy the Spanish ecclesiastical establishment still enjoyed as leaders of all Iberian Christians and cast it on the Carolingian side, thus helping to enhance Charlemagne's desired image as the champion of Christendom.

\footnotetext{
10 Isla (1998a).

11 Ed. Romero-Pose (1985).

12 Ed. Díaz y Díaz (1976) 239-242.

13 On adoptionism, see d'Abadal (1949); Barbero and Vigil (1978) 311 ff.; Cavadini (1993); Isla (1998a) and Fernández Conde (2000) 101 ff.

14 Royal Frankish Annals, Revised version, ed. Kurze (1895), s. a. 792.

15 Royal Frankish Annals, ed. Kurze (1895), s. a. 794. See also Concilia Francofordiensis Epistola synodica ad praesules Hispaniae Missa, PL, 101, cols. 1331-1346, whose redaction is normally attributed to Alcuin.

16 Wolf (1988) and Fernández Conde (2000) 105 ff.
} 
On the smaller scale, the role played by some Asturian clerics in the overthrow of adoptionism is too great to go unnoticed. ${ }^{17}$ In fact, the early date at which Beatus himself declared the debate to have gained notoriety not only in Spain, but in Francia too, ${ }^{18}$ makes me wonder whether it was not this party's strategy to bring the whole affair as high as possible, in order to secure Frankish intervention. In doing so, they would arguably put themselves in a stronger position to force the Asturian élites - both secular and ecclesiastical - to allign with them.

A thorough analysis of those ecclesiastical texts points to major political changes taking place in Asturias in the 780s. This is consistent with the more explicit indications that can be gathered in the $790 \mathrm{~s}$ from the earliest pieces of historiography. Again, the developments in the Carolingian milieu seem to have been determinant in shaping the Asturian ideology and practices.

In the context of the late eighth-century Carolingian build-up in northern Iberia, it is hardly surprising that a new, strongly consistent picture of the ending of Visigothic Spain was created. Texts such as the so-called Chronologia regum gothorum, Moissac Chronicle and Aniane Chronicle, probably composed in Caroligian-driven Septimania, ${ }^{19}$ share a number of distinctive features; for instance, they blame the loss of Spain to the Arabs on King Witiza's sins and vices; they too misdate the Arab invasion to 714; more importantly, in their account the Visigothic period is rendered as definitely over, and a new period opens up under Frankish rule. Thus, the Chronologia regum Gothorum declares:

Roderic reigned for 3 years. In this time, in the aera 752 [AD 714] the Sarracens were summoned because of the country's troubles, and they occupied the Spains, and seized the kingdom of the Goths, which hitherto they stubbornly possess in part. And they struggle with the Christians night and day, and they daily fight until God's predestination orders that they be cruelly expelled.

\footnotetext{
17 Beatus was the first to attack Elipandus's teaching, according to the most renowned adoptionist polemist, bishop Felix of Urgell, in the few preserved fragments of a letter sent by him to Alcuin. See Levison (1946) 316-317.

18 Beatus, Adversus Elipandus, ed. Löfstedt (1984), p. 9.

19 PL, 83, cols. 1115-1118. For details on the manuscripts, see Martin (1997), p. 17, n. 18. For the date of composition, see Barbero and Vigil (1978) 240-244.
} 
The kings of the Goths perished. In total they add up to 304 years (...)

In the aera $(\mathrm{x})$ reigned Charles, king of the Franks and patricius of Rome. ${ }^{20}$

Here the Visigothic kingdom is, as it were, officially pronounced dead (Reges Gothorum defecerunt) and, following a short computistic summary, the next entry implies that the fight against the Arabs is to be led thereafter by the Franks. ${ }^{21}$ The Moissac Chronicle is likewise clear in stating that, after their defeat to the Arabs, the reign of the Goths concluded: "The Goths were defeated by the Sarracens, and thus ended the reign of the Goths in Spain and in less than two years the Sarracens subjected almost all of Spain". ${ }^{22}$ This interpretation fits nicely the aforesaid ecclesiastical developments and the general mechanisms of political legitimation within the Carolingian context: ${ }^{23}$ power changed hands at God's will, and Charlemagne was the present-day God-favoured leader, his unending victories being the most obvious of all proofs. Both his commanding the elimination of all heretic thought from the Church and his leading the fight against the Barbarians - Arabs included - were pivotal in this scheme. And Spain was a field where both notions converged naturally: the translation of power from the Goths to the Franks had already been effected $;^{24}$ the condemnation of adoptionism came to legitimate a similar shift in the ecclesiastical sphere.

Turning again to the Asturians, their close participation in the 780s Carolingian ecclesiastical policies — most evidently revealed by

${ }^{20}$ PL, 83, col. 1118: Rudericus regnavit ann. III. Istius tempore era 752 farmalio terrae Saraceni evocati Hispanias occupaverunt, regnumque Gothorum ceperunt; quo adhuc usque ex parte pertinaciter possident; et cum Christianis die noctuque bella ineunt, et quotidie confligunt dum praedestinatio usque divina de hinc eos expelli crudeliter jubeat. Reges Gothorum defecerunt. Sunt sub uno ann. 314 (...) In era (x) regnavit Carolus Francorum rex et patricius Romae... The aera date for Charlemagne's accession is illegible in one manuscript, while the other wrongly gives that of Charles Martel: 727; see Martin (1997), p. 19, n. 19.

21 Martin (1997), p. 19.

22 Chronicon Moissacensis, ed. Pertz (1826) 290: Gothi debellati sunt a Sarracenis, sique regnum Gothorum in Spania finitur et infra duos annos Sarraceni pene totam Spaniam subiciunt.

${ }^{23}$ See the chapter by P. Fouracre in this same volume.

${ }^{24}$ In a similar fashion to that of the Septimanian texts, in northeast Spain the traditional Visigothic Laterculi - running down to the $710 \mathrm{~s}$ - were added notices from the late eighth-century onwards, leaving most of the eighth century blank. See, by way of example, the piece contained in ms. Escorial Z.II.2, fol. 6, ed. García Moreno (1975), in which the notice of the extinction of the Visigoths is followed by Charlemagne and Louis the Pious. 
their joint strategy about adoptionism - also had a historiographical counterpart. By the very end of the eighth-century or the earlier years of the ninth, a brief historical piece was written in Asturias. Although lost in its original form, traces of it are to be found in a number of later manuscripts. ${ }^{25}$ The part thereof which can be seen as derived from the original core, is a twofold text, comprising a brief summary of the reign of the Visigoths and a list of the Asturian kings down to Alfonso II's accession in 791. Although some northeastern features are here missing, such as the 714 date, or Witiza's liability for the defeat to the Arabs, the main argument remains the same: that the Visigoths were gone for good, and the Asturian kings belonged to a new period, even allowing for a five-year Arab interregnum that has the virtue of making even more obvious the breach between both. Thus, we read in the so-called Annales Portucalenses Veteres (long redaction $=$ Chronica Gothorum):

In the aera 349 [AD 311] the Goths left their country.

In the aera 366 [AD 328] they entered Spain, and reigned there for 383 years.

From their country they travelled to Spain for 17 years

In the aera $749[\mathrm{AD} 711]$ the Goths were expelled from Spain.

In the aera 750 [AD 712] the Sarracens obtained Spain.

Before the lord Pelagius reigned, they reigned over Spain for 5 years. . . ${ }^{26}$

Again, the idea that the Goths were dead and gone stands out, but in this case, the natural succession falls on the Asturians, but the gap between him and the Visigoths is not to be missed. Fortunately, another independent piece of evidence comes in support of this conclusion. A charter issued by King Alfonso II to the church of San Salvador de Oviedo in 812 included, by way of preamble, a prayer packed with historical references:

Because you [God] are King of Kings, reigning over all things, heavenly and earthly, and granting worldly justice, in order to provide the peoples of the earth with worldly justice, you distribute kings, laws and judgements. By whose [God's] gift, among the kingdoms of several

25 See Huete (1994) 12 ff.

${ }^{26}$ Era CCC XL IX egressi sunt Gotti de terra sua. Era CCC LX VI ingressi sunt Hispaniam et regnaverunt ibi annis CCC LXXX III. De terra autem sua pervenerunt ad Hispaniam per XVII annos. Era septingesima quadragesima nona expulsi sunt de regno Hispanie. Era 749 Sarraceni Hispaniam adepti sunt. Antequam Dominus Pelagius regnaret Sarraceni regnaverunt in Hispania annis V. (David (1947) 291-292). 
other peoples, the Goth's victory shone nonetheless. But because You [God] were offended by their prepotent proudness, in the era 749 [AD 711], the kingdom's glory, together with King Roderic, was destroyed. He well deserved to suffer the Arab's sword. Of which plague, by your right hand - Christ - was your servant Pelagius saved, who, having been elevated to princely power, fought victoriously, hit the enemy, and defended the Christian and Asturian people with sublime victory. ${ }^{27}$

Links with the discourse of Carolingian legitimacy become here even more apparent. There is a whole enunciation of the notion of translatio imperii. It is God who, in order to secure justice, distributes power among kings. And then, victory - almost a metaphore for God's judgement - is the proof of divine support for rulers, for victory indeed was the Goths' single claim to reign (clara refulgit Gothorum victoria). Moreover, it was because of the latter's proudness that victory was denied to their king. Since the Arabs could not possibly be presented as God-favoured, their victory is rather described as a plague. Then - ignoring a substantial chronological gap - it was Pelagius, touched by God with victory, who rose to rulership.

The 812 charter is of great help in establishing the kind of political identity that had become official in the entourage of Alfonso II. One which was strongly dependent on wider Carolingian developments, and was based upon rejection of, and distinction from the Visigoths. The notion of an independent Asturian Church, with no links to the southern post-Visigothic Christians, had its counterpart in a God-devised rupture with Visigothic royalty and history.

\section{The Ninth-Century Visigothic Revival}

Thin as the evidence is, the aforementioned pieces of historical writing suffice to indicate which kind of vision of the Asturian origins

\footnotetext{
27 Floriano (1949), doc. 24: "Et quia tu es rex regum regens celestia simulque terrestria, diligens in temporaliter iustitiam temporaliter vero terrarum populis pro optinenda iustitia distribuis reges, leges atque iudicia. Cuius dono inter diversarum gentium regna non minus in terminis Spaniae clara refulgit Gotorum victoria; sed quia te offendit eorum prepotens iactantia, in era dcc xl viiii simul cum rege Roderico regni amisit gloria. Merito etenim arabicum sustinuit gladium. Ex qua peste tua dexteera Christe famulum tuum eruisti Pelagium; qui in principis sublimatus potentia victorialiter dimicans hostes percusit et christianorum asturumque gentem victor sublimando defendit. Cuius ex filia filius clariori regni apice Froila extitit decoratus. Ab illo etenim in hoc loco qui nuncupatur Ovetao fundata nitet aeclesia tuo omine sacra tuoque sacro nomine dedicata... "On this charter, see Fernández Conde (1971) 119-120 and Floriano (1975).
} 
had been established in the royal entourage by the early ninth-century. Thereafter we do not have any trace of comparable writings until Alfonso III's historiographical cycle set out in the 880s. As I said before, the components of this group are so outstanding that they have tended to obscure all previous developments. This is even more important because the historical perspective they reveal is in striking contradiction with many features of what was 'official' history in the time of Alfonso II. Of paramount importance is that by the 880s the former rejection of a Visigothic identity had been replaced by the notion that the Asturian kings were the biological, dynastic and historical continuators of the Goths.

The rising neo-Gothic theory seems to respond to a combination of historical changes taking place from the mid-ninth century across the Iberian peninsula. During the later years of Alfonso II's long reign (791-842), Carolingian influence in northwestern Spain declined seriously, while the northeast remained under Frankish rule, albeit with ever increasing autonomy. Cultural contacts and exchange surely lived on, but the events taking place in the northwest ceased to be so dependent on the wider frame of Frankish policies. Nevertheless, the 'Carolingian factor' had already done its job. Having grown under its cover, Asturias was in the 840s a fairly developed polity by Iberian northern standards. It was even a valid reference for those opposing the Cordoban emirs, as witnessed by the repeated military expeditions against Asturias - increasingly seen as a major disturbing factor in the northern frontier - and the remarkable fact that in the later years of Alfonso II a notorious Muslim rebel could seek and obtain exile in Asturias. ${ }^{28}$ All this seems to be pointing towards a rising new scene.

Ramiro I's short reign - under which a different branch of the Asturian royal families replaced that of Alfonso II-surely was of paramount importance, as C. Estepa has rightly pointed out. ${ }^{29}$ A number of factors seem to indicate that some sort of consensus was then reached that made it possible to further the kingdom's political development, both in internal complexity and territorial expansion. This may well also relate to a greater degree of formalization

\footnotetext{
28 Ibn Hayyan, Muqtabis II-1 ed. Makki and Corriente (2001) 298 ff.

29 Estepa (1992).
} 
of the relationship between kings and magnates, probably by means of considering as royal officers those aristocrats who ruled de facto over specific territories. Magnates begin by then to be termed comitesa denomination implying both a high social status and a formal denial of royalty - which is certainly relevant for a king who had to face major aristocratic opposition in his early years. ${ }^{30}$ It is utterly plausible that a consensus of this kind among the Asturian ruling elites - king and magnates - underlay the great territorial expansion operated in the second half of the ninth-century, under kings Ordoño I and Alfonso III. In a rather short time, the Asturian territory grew to over twice its size, for the greater benefit of king, magnates and clerics, who found in the newly gained plateau lands an inmense source of revenue and power. This is the essential context within which the royal chronicles must be considered.

At the same time, important changes were taking place in the south. By the mid-ninth century conversions to Islam had increased to an extent that the status of non-Arab population within the society of al-Andalus became a relevant issue, nonetheless because among those of Iberian provenance, whether Christians or Muslims, there was a clear notion of descending from the Visigoths. ${ }^{31}$ The second half of the ninth century saw no shortage of tensions between the central power and relevant groups, such as the Mozarab (Christian) communities - most famously Toledo - or the Berber clans, but also an increasing number of indigenous converts trying to find a position of their own within an Arab dominated society. A few from their ranks (the so-called Muwalladun) eventually rebelled against their rulers, gathered armed retinues and managed to hold control over small territories where they were hard to fight. ${ }^{32}$ This situation was not definitively overcome until the reign of Abd al-Rahman III (912-961), and more so by way of negotiation than military defeat.

It has been pointed out that Visigothic descent - frequently referring to king Witiza - seems to have become a sort of sign of iden-

\footnotetext{
${ }^{30}$ All the more interesting, considering that J. Fernández Conde may very well be right in suggesting that young Ramiro I could have been a rebel against Alfonso II, and even have ruled in parallel a part of the territory; Fernández Conde (1997).

${ }^{31}$ García Moreno (1999).

32 Acién (1994); cf. Manzano (1991b); Fierro (1998); Wasserstein (2002). In this brief summary I am much indebted to comments from Maribel Fierro.
} 
tity for many non-Arab Andalusians, whether Christian or Muslim. That such an ancestry was invented in most cases makes no less a case for the relevance of the notion itself. Yet, for all the echoes of 'Visigothic feudalism' that can be spotted in the muwalladun rebels, ${ }^{33}$ the greatest issue remained that of which position the converts should enjoy within the Andalusian society. In this debate, the reconsideration of the Arab invasion became a very sensitive issue, central to a change in the political identity that gradually set in, and remained so until the end of the Caliphate in the eleventh century. The modalities of subjection (whether pact or conquest), the status of the conquered lands and peoples, the position of converted Visigothic aristocrats, all became important matters in defining a legitimate vision of the complexities of ninth-century al-Andalus. ${ }^{34}$ This would ultimately lead to a new historical consciousness that needed to account for more than the ethnic divisions among the invaders, and integrate the natives, the main representative of which would be the famous historian Ahmad al-Razi.

It is likewise relevant that those southern Christians who kept to their faith - the so-called Mozarabs - found themselves in a profoundly contradictory situation. On the one hand, the dominant Arabic language and culture permeated all social groups, even those who resisted conversion. Most Spanish Christians adapted themselves into the Islamic political framework, particularly in urban contexts, and most of all in Córdoba; some even made it into the administrative system, holding offices and taking part in the normal functioning of government. ${ }^{35}$ Since the early days of Arab rule, the general trend for accomodation and even cooperation with the new rulers had greatly disappointed a minority who rather favoured resistence. Traces of this attitude were already present in the 780s, when adoptionism first burst out. ${ }^{36}$ By the mid-ninth century a combination of factors led to another tide of active contestation from non-conformist Christians, the so-called 'martyrs of Córdoba'. ${ }^{37}$

In this turbulent context there was plenty of room for messianic and apocalyptic thought. From the mid-ninth century, several

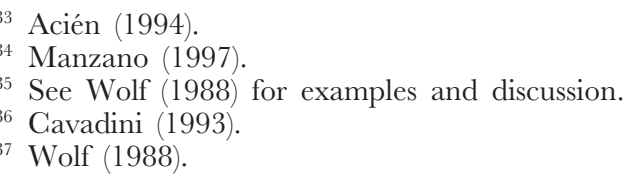


mutually influenced lines of such discourses spread among Christians, Jews and Muslims. ${ }^{38}$ Premonitions of the advent of a new era were easily turned into predictions of an immediate ending for either the Ummayad or Arab rule in Spain at all. ${ }^{39}$ As early as the 850s Alvarus of Córdoba already pointed out the existence of prophecies about the imminent end of Muslim rule. The 852 Toledo rebellion may have been fuelled by another wave of prophetic expectancy. This all, albeit collateral, may well have contributed to shaping the milieu from which the Cordoban martyrs emerged. ${ }^{40}$ In the following years, prophecies and omens went on being adapted and reinterpreted as the consecutive dates for doom proved unreliable. By the 870s at least, one such branch of apocalyptic thought seems to have developed among those Andalusian groups who based their political identity upon the Visigothic inheritance, arguing that Muslim rule would be destroyed by nothing other than a Visigothic revival. A similar notion may well have been attached to the most relevant of all muwallad rebels, Umar ibn Hafsun, but this must be seen as another aspect of a growing trend among non-Arab groups in al-Andalus.

The most explicit formulation of these prophetic expectations was set up in al-Andalus sometime in the 870s. By adapting an oriental prophetic and computistic tradition to the Iberian context, the idea was construed that Arab rule over the Goths was to end when the latter should recover, and dated this to 884. The Goths were identified with the biblical people of Gog, and the Arabs with that of Magog. This was a means of reinforcing the notion of Visigothic revival by wrapping it up in Bible-based legitimacy. This construct, and other similar ones, surely became widespread in late ninth-century alAndalus, but we know little about the effects they had. By contrast, a lot more is known about the impact in the north. ${ }^{41}$

By those years, the Asturian kingdom had grown big enough to be a major cause of concern for the emirs of al-Andalus, and it acted as a hegemonic power in the north, frequently intervening in the troubled Riojan frontier. It was only natural that non-conformist

\footnotetext{
${ }^{38}$ Gil (1978-1979); Fierro (1998).

39 On the notorious case of ninth-century author Ibn Habib, see Aguadé (1991) 88-100.

${ }^{40}$ Gil (1978-1979).

41 Torrente (2002).
} 
southern Christians should turn to the Asturian kings. During Ordoño I and Alfonso III's reigns there was frequent communication between the Asturians and the southern Mozarabs, mainly those of rebellionprone Toledo. Mozarab clerics seeking exile in Asturias were pivotal in the cultural development of Alfonso III's epoch. They were also major political collaborators, who helped adapt Asturias to many of the conceptions they brought from the south, most remarkably that of a Visigothic revival.

To turn into champions of Gothicism a king and dynasty whose own historiographical tradition largely consisted of rejecting such an inheritance was surely no little task. The finest formulations of the neo-Gothic ideal were developed at the royal see of Oviedo in the early years of Alfonso III. It was surely a Mozarab cleric working at Oviedo who combined the Gog and Magog prophecy-computations adapted - with several passages about the end of the Gothic kingdom, the survival of the Gothic people in al-Andalus, and some fairly accurate lists of Arab governors; then he added an interpretation of the whole piece predicting for $\mathrm{AD} 883$ the immediate ending of Arab rule, which deed was to be effected by no one other than Alfonso III. This was the so-called Prophetic Chronicle, which greatly influenced the Albeldensis. ${ }^{42}$

Neo-Gothicism further developed into the main ideology presiding over the new Asturian historiographical cycle. Its main purpose was to present the Asturian kings as the legitimate cross-Iberian Christian leaders, ideologically entitled to recover the realm and glory that the Visigoths once held. Yet, its formulation was far from simple, and its ramifications were manifold. In the early years of Alfonso III, there were a number of recent political developments needing legitimation, of which Iberian hegemony was only the most general one. In order to accomplish this, the Chronicles of Alfonso III's cycle deployed a powerful, multifaced discourse in which the Asturian past was revisited, the pre-existent undesired historiographical elements deactivated, and new explanations provided to fill the legitimation voids of the time. Clearly, not all historical works were similarly consistent in doing so. The Albeldensis Chronicle is dominated by this hegemonic thought, but contains many elements from earlier or contemporary conflicting discourses. This is to some extent - but only

42 Ed. Gómez Moreno (1932) 622-628. 
to some extent - corrected by the Rotensis, but this work maintains much of the past, nonetheless because in many passages it is evidently contesting other opposing arguments. The Ovetensis, instead is a much more consistent, carefully filtered text, that even puts aside some of the issues that were of relevance for the Rotensis and goes ahead in establishing direct links, not with the last, declining Visigothic kings, but with the most glorious of that breed: Leovigild, Reccared, Reccesvinth and Chindasvinth. ${ }^{43}$

I have started by noting that the figure of Alfonso I stands out in the Chronicles of Alfonso III's time, among several other eighthcentury rulers. The argument I will follow in the next pages is that the great importance attached to him was because he was the node crossed by a number of discourse lines which were essential in gaining legitimacy for issues of the utmost relevance in the 880s. He was indispensable for the internal consistency of a whole vision of the past, even if that meant that the inherited 'historical truth' should be greatly distorted.

\section{Alfonso I in the Neo-Gothic Discourse}

The Albeldensis, Rotensis and Ovetensis chronicles roughly agree about Alfonso I, although with differences of detail from one to the other.

Adefonsus, Pelagius's son-in-law reigned for 18 years.

This was the son of Petrus, duke of Cantabria, and, as he came into Asturias, he took Pelagius's daughter, Bermesinda, by Pelagius's command.

And, on achieving power, he led many fights with God's help. He also invaded the towns of León and Astorga, long posessed by the enemy. The so-called Gothic Plains he depopulated to the river Duero and he extended the Christians' realm.

He was loved by God and men. He died due to natural causes. ${ }^{44}$

\footnotetext{
${ }^{43}$ Isla (1998b).

${ }^{44}$ Alb. XV, 3: "Adefonsus Pelagi gener rg. an XVIII". Iste Petri Cantabrie ducis filius fuit. Et dum Asturias uenit, Bermisindam Pelagi filiam Pelagio precipiente accepit. Et dum regnum accepit, prelia satis cum Dei iubamine gessit. Hurbes quoque Legionem atque Asturicam ab inimicis possessas victor inuasit. Campos quem dicunt Goticos usque ad flumen Dorium eremanit et Xpianorum regnum extendit. Deo atque hominibus amauilis extitit. Morte propria decessit".
} 
This brief portrait in the Albeldensis regnal list-eloquently entitled Ordo Gothorum Ovetensium Regum ("List of the Gothic kings of Oviedo") will suffice to present the main facts about Alfonso I: a) his victorious military campaigns; b) his family liasons; c) his moral qualities.

\section{Alfonso I's Military Activity}

This is the aspect of Alfonso I's reign to which the three chronicles conceded the greatest length of text. In all three, the king's activity was twofold: he fought victoriously against his enemies; he extended the limits of his realm. Both aspects must be considered separately.

About Alfonso I's campaigns, the Albeldensis Chronicle simply stated: “... on achieving power, he led many fights with God's help. He also invaded the towns of León and Astorga, long posessed by the enemy. The so-called Gothic Plains he depopulated to the river Duero and he extended the Christians' realm". ${ }^{45}$ The Chronicle of Alfonso III was much more explicit. Both recensions basically coincided, but the Ovetensis emphasized more the king's exemplary qualities. For clarity, I put in italics the main differences between them. The geographic implications of the Albeldensis and the Chronicle of Alfonso III are represented in Fig. 4.

\section{Rotensis:}

After his [Favila's] death, Alfonso was elected king by the whole people, and he held the kingdom's sceptre with God's grace. The enemy's boldness was always oppressed by him. Together with his brother Fruela, he frequently moved his troops and seized by combat many cities, that is: Lugo, Tuy, Oporto, Anegia, the metropolitan Braga, Viseu, Chaves, Ledesma, Salamanca, Numancia (now called Zamora), Ávila, Astorga, León, Simancas, Saldaña, Amaya, Segovia, Osma, Sepúlveda, Arganza, Clunia, Mave, Oca, Miranda, Revenga, Carbonaria, Abeica, Cenicero y Alesanco, and all the castles with their vills and hamlets. Killing all the Arabs by the sword, he took the Christians with him to the homeland. ${ }^{46}$

${ }^{45}$ Alb. XV, 3. See previous note.

${ }^{46}$ Rot. 13: "Quo (Favila) mortuo ab uniuerso populo Adefonsus eligitur in regno, qui cum gratia diuina regni suscepit sceptra. Inimicorum ab eo semper fuit audatia conprensa. Qui cum fratre Froilane sepius exercitu mobens multas ciuitates bellando cepit, id est, Lucum, Tudem, Portugalem, Anegiam, Bracaram metropolitanam, Uiseo, Flauias, Letesma, Salamantica, Numantia qui nunc uocitatur Zamora, Abela, Astorica, Legionem, Septemmanca, Saldania, Amaia, Secobia, Oxoma, Septempuplica, Arganza, Clunia, Mabe, Auca, Miranda, Reuendeca, Carbonarica, Abeica, Cinasaria et Alesanzo seu castris cum uillis et uiculis suis, omnes quoque Arabes gladio interficiens, Xpianos autem secum ad patriam ducens". 


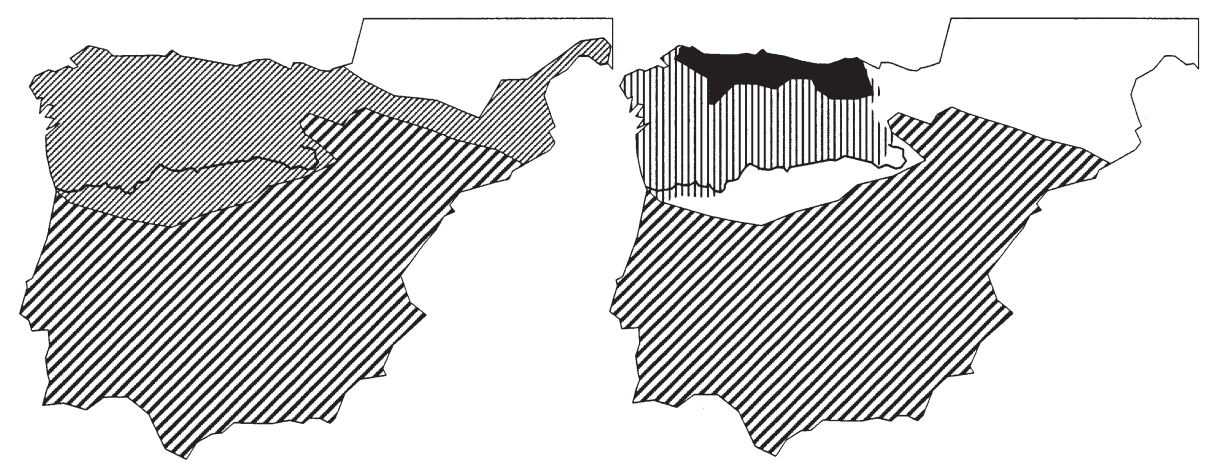

Fig. 2: The evolution of the Iberian northwest from the mid-eighth to the late ninth century. The end of Arab control of the Duero plateau (left) and the Asturian expansion under Ordoño I and Alfonso III (right).

\section{Ovetensis:}

The following facts prove how great his grace, virtue and authority were: together with his brother Fruela, he led many fights against the Sarracenes and he seized many cities once oppressed by them, that is, Lugo, Tuy, Oporto, the metropolitan Braga, Viseu, Chaves, Agata, Ledesma, Salamanca, Zamora, Ávila, Segovia, Astorga, León, Saldaña, Mave, Amaya, Simancas, Oca, Veleia of Álava, Miranda, Revenga, Carbonaria, Abeica, Brunes, Cenicero, Alesanco, Osma, Clunia, Arganza, Sepúlveda, and all the castles with their vills and hamlets. Killing all the Arabs who occupied those cities, he took the Christians with him to the homeland. ${ }^{47}$

These two must be among the most ever quoted passages in early medieval Spanish historiography, since they lay at the foundations of the whole 'Reconquista' ideology, as Barbero and Vigil eloquently exposed. ${ }^{48}$ Fig. 2 shows the situation in Iberia between the mideighth and the late ninth century. After the first two decades of

47 Ovet. 13: "Post Faffilani interitum Adefonsus successit in regnum, uir magne uirtutis filius Petri ducis, ex semine Leuuegildi et Reccaredi regum progenitus; tempore Egicani et Uittizani princeps militie fuit. Qui cum gratia diuina regni suscepit sceptra. Arabum sepe ab eo fuit audacia conpressa. Iste quante gratie uel uirtutis atque auctoritatis fuerit, subsequentia acta declarant: simul cumfratre suo Froilane multa aduersus Sarracenos prelia gessit atque plurimas ciuitates ab eis olim oppressas cepit, id est, Lucum, Tudem, Portucalem, Bracaram metropolitanam, Uiseo, Flauias, Agata, Letesma, Salamantica, Zamora, Abela, Secobia, Astorica, Legione, Saldania, Mabe, Amaia, Septemanca, Auca, Uelegia Alabense, Miranda, Reuendeca, Carbonaria, Abeica, Brunes, Cinisaria, Alesanco, Oxoma, Clunia, Argantia, Septempublica et cunctis castris cum uillis et uiculis suis; omnes quoque Arabes occupatores supra dictarum ciuitatum interficiens Xpianos secum ad patriam duxit".

${ }_{48}$ Barbero and Vigil (1978) $216 \mathrm{ff}$. 


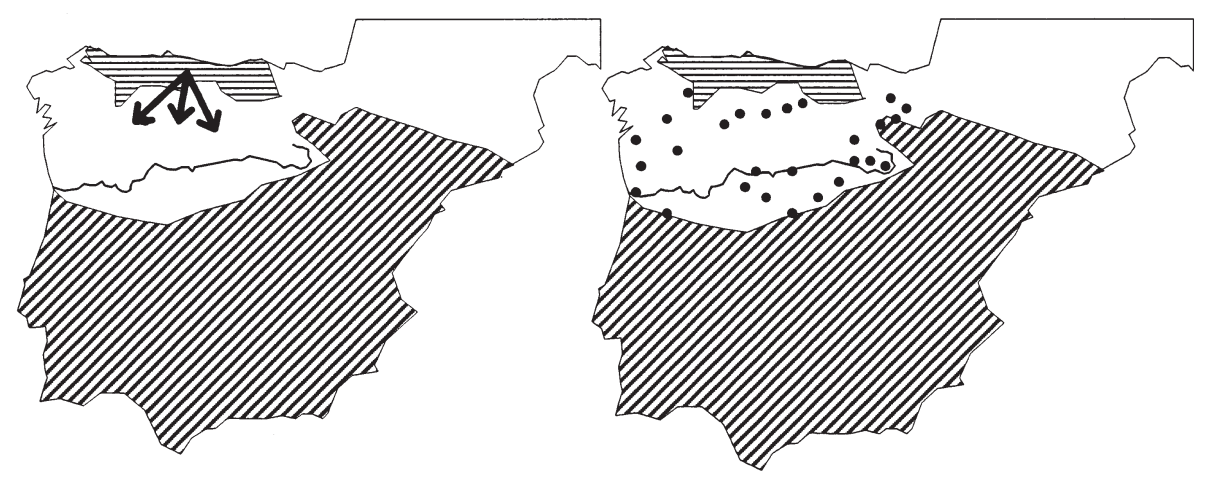

Fig. 3: Alfonso I's attacks on the plainlands, according to the Albeldensis (left) and the Chronicle of Alfonso III (right).

Muslim rule in Iberia, the territory controlled by them was significantly reduced. Between 730 and 750 Arab rule in southern Gaul was eliminated. More importantly, between 740 and 760, al-Andalus underwent great political unstability: a revolt of the numerous Berber troops, continued party struggles, and finally, the take over by the Ummayad refugee Abd al-Rahman I, who succesfully managed to claim power, but could not establish his rule firmly until the late 760s. Amidst those troubles, Arab rule in the Iberian northwestern quadrant faded out. The Central Mountains became the limit of their effective control (Fig. 2, left). ${ }^{49}$ This reduction of Arab-ruled territory can hardly be credited to the Asturian kingdom, which was by then a tiny northern spot, plausibly ruled by a number of aristocratic lords, and which had no expectations of replacing the Arabs in ruling the plateau. Recent research suggests that in the Duero basin the population remained largely on its own, and, for over a century, it lacked any superior political articulation, until it was annexated by the Asturians in the second half of the ninth-century (Fig. 2, right).$^{50} \mathrm{I}$ have indicated above that this was only possible after major political developments took place, some during Alfonso II's reign, others after the convergence of royal and aristocratic interests established under Ramiro I.

\footnotetext{
49 For details, see Manzano (1991a).

50 Escalona (1991); Escalona (2000a) Escalona (2002). For a detailed discussion in English, see Castellanos and Martín Viso (forthcoming).
} 
But the story the chronicles told was quite a different one. They had it that in the mid-eighth century, as al-Andalus agitated in troubles, Alfonso I seized the opportunity to lead a series of systematic attacks on the plainlands, ultimately causing the complete depopulation of all cities in the Duero basin. The Arabs got killed, the Christians were taken to the north. However, this view was not shared by the three texts in the same terms. Whilst the Albeldensis (Fig. 3, left) highlighted Alfonso I's campaigns, it only credited him with having attacked León and Astorga, and having depopulated the so-called Gothic Fields (modern Tierra de Campos, a region in province Palencia). Instead, it was the royal chronicles that gave the most exaggerated picture, one in which Alfonso I was supposed to have raided an astounding number of cities and depopulated a really huge territory (Fig. 3, right).

This was complemented by Alfonso I's other notable achievement. The Albeldensis merely said that he 'extended his territory', but the royal chronicles - the passage reads almost the same in both recensions - provided a list of the territories he allegedly controlled and those which he did not. The Iberian northwestern quadrant was thus divided in two parts, the lands under Asturian rule and those which they emptied of all dwellers:

By that time Primorias, Liébana, Trasmiera, Sopuerta, Carranza, Bardulias - now called Castile - and the coastal side of Galicia were populated; yet it is said that Álava, Biscay, Alaón and Orduña were always possessed by their inhabitants, as Pamplona and Berrueza were. ${ }^{1}$

Unlikely as it seems that Alfonso I should have ever enjoyed the means - or even had the aim - of depopulating a territory several times the size of his kingdom, what we must now look at is the role this notion played in the chronicle discourse. ${ }^{52}$ The account of the

51 Ovet, 14. "Eo tempore populatur Asturias, Primorias, Liueria, Transmera, Subporta, Carrantia, Bardulies qui nunc uocitatur Castella et pars maritimam Gallecie; Alaba namque, Bizcai, Aizone et Urdunia a suis reperitur semper esse possessas, sicut Pampilonia [Degius est] atque Berroza. Hic uir magnus fuit. Deo et ominibus amauilis extitit. Baselicas multas fecit. Uixit in regno a. XVIII. Morte propria discessit". On the meaning of populare, see Menéndez Pidal (1960), Barbero and Vigil (1978) 225-228 and, more recently, Escalona (forthcoming).

52 For criticism of the role that the 'depopulation and repopulation of the Duero basin' played in Spanish historiography see Barbero and Vigil (1978) $219 \mathrm{ff}$. I have written - and spoken - at length trying to show that, by taking this construct at face value, traditional historians have not only blurred this part of the Iberian early 
reign of Alfonso III's father, Ordoño I (850-866), provides the first clue. The Albeldensis merely stated that "he extended the Christians' realm", ${ }^{33}$ but the Rotensis elaborated more: ". . the long abandoned cities, that is, León, Astorga, as well as Tuy and Amaya, he surrounded with walls and gave them high gates, and he populated them in part with his own people, in part with those coming from Spain". ${ }^{54}$ Then, the Ovetensis made an even more explicit connection with Alfonso I: "he repopulated the long abandoned cities, of which Alfonso the Elder [Alfonso I] had expelled the Arabs, that is, Tuy, León, Astorga, and Amaya Patricia".55 The combination of raiding the plateau and absorbing the northern lands is an image which probably has little to do with the eighth century, but is most relevant for the late ninth. Most cities allegedly attacked by Alfonso I one hundred years earlier where actually in the ninth century either seized by Ordoño I, or by his son, or were at least the latter's target for future expansion. The chroniclers' discourse becomes clear: Alfonso divided the northwest in two different spheres of status: a) the lands continually inhabited and ruled by the Asturians; b) the depopulated lands, which were open to be seized and exploited by the Asturian kings and elites. Then, the ninth-century Asturian kings began to recover and repopulate them with either their northern subjects or with Mozarabs from al-Andalus. In the kingdom of the new Goths there was only room for these two identities, while a complete denial was effected of the local population and of any power structures they might have developed during the hundred years in which they lacked higher rulers. This was obviously a very sensitive issue of Alfonso III's reign, that urgently needed to be legitimated.

Now, some elements in those accounts of Alfonso I's glorious deeds make me think they could have been largely made up to fill the needs of the chroniclers' discourse. Moreover, the way they were

medieval history, but also put a great obstacle to the development of modern settlement archaeology in the region, which is only recently emerging: Escalona (1991); Escalona (2000a); Escalona (2000b), Escalona (2001), Escalona (2002), Azkárate and Quirós (2001).

${ }^{53}$ Alb. XV, 11.

${ }^{54}$ Rot. 25: Civitates ab antiquitus desertas, is est, Legionem, Astoricam, Tudem et Amagiam Patriciam muris circumdedit, portas in altitudinem posuit, populo partim ex suis, partim ex Spania advenientibus implevit.

${ }_{55}$ Ovet. 25. Civitates desertas ex quibus Adefonsus maior Caldeos eiecerat iste repopulavit, id est, Tudem, Astoricam, Legionem et Amagiam Patriciam. 
presented even seems to indicate that the version in the royal chronicles could be set up as an answer to alternative conceptions of the Asturian past. To do so meant to develop a very complex line of discourse, and the chroniclers - fortunately for us - could not keep some inconsistencies from slipping into their narration.

First, the passage about the lands Alfonso I effectively ruled may raise our suspicions at one specific point. The text declares that Castile, among other territories, was absorbed into the Asturian kingdom in the time of Alfonso I, but Álava belonged to a group of Basque territories which were said to have always been 'in the possession of their inhabitants'. This picture may well describe the historical situation of the region sometime between the mid-eighth and mid-ninth centuries, but was clearly at odds with the rest of the chronicle's discourse about Álava.

After having declared that in Alfonso I's time Álava was possessed by its own inhabitants, we first hear about it in the Rotensis account of the reign of Fruela I (Alfonso I's son). ${ }^{56} \mathrm{He}$ is said to have defeated the "Basque rebels" (Uascones rebellantes superavit), a shocking word to describe those who possessed their own country. Then we are told that Fruela took with him a woman called Munina for his wife. Munina bore Fruela a son, the future Alfonso II. The Ovetensis insists in presenting Munina as a slave, by saying that "he defeated and tamed the Basque rebels; from the Basque booty he ordered a certain adolescent called Munia to be reserved for him, and he bound her in royal wedlock...". ${ }^{57}$ Putting this all together, the episode rather looks as standard hostage-taking; Munina surely belonged to the local aristocracy, so marrying her would lay the foundations of some - if volatile - alliance, which enabled young Alfonso II to seek refuge by his mother's relatives when expelled from the throne by Mauregato. ${ }^{58}$ Thereafter we only find occasional mentions of Vasconia and the Vascones, until the reign of Ordoño I, in which we are told that the king had to defeat a coalition of Basques and Sarracens, and he subjected the first to his rule. ${ }^{59}$ Alfonso III himself had to do likewise in $868{ }^{60}$ García de Cortázar has rightly pointed out that

\footnotetext{
56 Rot., 16.

57 Ovet., 16.

58 Rot.-Ovet., 19. Dacosta (1992); García de Cortázar (1997) 115-116.

59 Rot., 25.

60 García de Cortázar (1997) 116.
} 
the ninth-century Asturian policies about Álava and Pamplona could account for the inclusion of several places from that area in the list of cities attacked by Alfonso I, according to the Ovetensis. ${ }^{61}$ Again, we find that the eighth-century events point directly to contemporary sensitive political issues. The next image we see of Álava is one of full subjection and cooperation. The regional leader was a comesimplying a royal officer, whichever perception the locals could have of him - who acted at the kingdom's eastern frontier under the king's command. It is pretty evident that in the ninth century Álava represented a certain source of trouble, while Castile did not. ${ }^{62}$ This is why very little is said about how Castile was incorporated into the kingdom, while the Alaban reputation as rebels was often repeated. A secondary line of discourse can be identified in the royal chronicle purporting to demonstrate that Álava was subjected - albeit reluctantly - to Asturias.

But Rot.-Ovet., 14 tells it differently: Castile belonged to Asturias while Álava did not. The fact that the wording is so similar in both recensions makes me think that the chronicles could be dealing here with a piece of earlier material. The picture, though, does not seem to fit the mid-eighth century either. As I noted above, in this period all but the westernmost of the Iberian northern polities seem to have been in the sphere of the Carolingians. The earliest Arab attacks on them are better explained as a reaction to this growth of Frankish influence. In this context, it is most plausible that Castile and Álava were small independent territories heavily under Carolingian influence. A trace of this situation may have survived in the Arabic sources, in which Álava and Castile are referred to - often together - as separate, distinct units (Alaba wal Qila), whereas the Asturian kingdom is normally termed filliqiyya (Galicia). The fact that a separate name was in use for Álava and Castile may be reminiscent of their being formerly independent units. It is therefore, plausible that the paragraph in question originally referred to another king, but was intentionally ascribed to Alfonso I.

So it seems that the chroniclers' strategy in this passage was to move a great milestone in the kingdom's political development from its chronological context to that of Alfonso I. This argument would

\footnotetext{
${ }^{61}$ García de Cortázar (1997) 117.

62 García de Cortázar (1997) 115-116.
} 
surely be too feeble, should it be an isolated example. But a comparable procedure seems to have been followed by the chroniclers regarding Alfonso I's greatest deed, namely, the devastation of the Duero basin. This, though, must be pursued through the Arab historians. ${ }^{63}$

The greatest landmark in pre-eleventh century history writing in alAndalus was the work of Ahmad al-Razi (888-955), the first to have articulated a coherent historiographical programme in which the Iberian Islamic history was considered as another element within the wider frame of Iberian history, rather than as a particular episode in the general history of Islam. Al-Razi is remarkable for having made use of a wide range of sources, including many of Christian provenance, either from Latin or from Arabic translations. His work, though, has not survived but in small fragments, as quotations within other authors' writings, most importantly the enormous Muqtabis, by eleventh-century historian Ibn Hayyan. Al-Razi's work was often quoted by Ibn Hayyan, but the first volume of the Muqtabis, dealing with most of the eighth century, is lost as well. Yet, a number of fragments from al-Razi also made their way- directly or indirectly via Ibn Hayyan - into the writings of Ibn al-Athir (1160-1234). Sánchez-Albornoz suggested that the Asturian stories in Mosul-based Ibn al-Athir derived from al-Razi, and reflected the latter's use of a lost Asturian chronicle from Alfonso II's reign. ${ }^{64}$ Although SánchezAlbornoz's conception of such a lost text can hardly be sustained now, ${ }^{65}$ it seems obvious that al-Razi had access to historical material of Christian provenance whose discourse cannot be conciliated with that of the Chronicle of Alfonso III. The passage of al-Razi I am

${ }^{63}$ In dealing with the Arabic sources, I am particularly indebted to Maribel Fierro, Laura Bariani, Luis Molina and Eduardo Manzano. See a recent overview of Arabic texts dealing with the Asturian kingdom in Maíllo Salgado (2002).

${ }^{64}$ Sánchez-Albornoz rightly noted that, although al-Razi was contemporary to the Oviedo chroniclers, and thus, could have known the Chronicle of Alfonso III, his quotations do not belong to these texts, but to different material. Sánchez-Albornoz (1967a); Sánchez-Albornoz (1967b); Sánchez Albornoz (1967c).

${ }^{65}$ Sánchez-Albornoz was more than keen to take at face value the connections between the Asturian kings and the Visigoths, as the royal chronicles had them. Although he detected the Carolingian elements in Alfonso II's reign, he saw it as a period of Visigothic restoration. But this picture is the result of the chroniclers efforts to translate Alfonso II's achievements into a 'neo-Gothic language'. SánchezAlbornoz described his hypothetical lost chronicle as full of Carolingian and neoGothic elements, which actually meant to mix up two different periods in Asturian historiography. 
now concerned with is to be found in two versions: the one transmitted by Ibn al-Athir:

In the same year 140 (757), after an eighteen year reign, Alfonso, king of Galicia died; he was succeeded by his son Fruela, who superseded his father in boldness, administrative abilites and firmness. He held absolute power and a glorious reign: he expelled the Muslims from the frontier strongholds and seized the city of Lugo, Portugal, Salamanca, Zamora, Ávila and Segovia. ${ }^{66}$

and the one transmited by Ibn Khaldun (1332-1406), then followed by al-Qalqashandi (1355-1418) and al-Maqqari (1590-1631):

Alfonso, son of Peter, died in 142 (759-760) after an eighteen-year reign. His son Fruela succeeded him. This reigned for eleven years, in which his power increased, for that was the precise time in which Abd al-Rahman [I] was busy founding his new dynasty. Fruela was able to recover Lugo, Oporto, Zamora, Salamanca, Segovia and Castile, which had been occupied by the Muslims during the Conquest. ${ }^{67}$

The connections between these passages ${ }^{68}$ and the aforecited fragments from Alb., XV, 3 and Rot.-Ovet., 15 are so evident that they must be related. Yet, it is outstanding that in the Arabic texts (as indeed in the Albeldensis), the Asturian attacks were much more limited, so totally unable to provoke the wholesale depopulation of the plateau; most importantly, in the Arabic versions it was not Alfonso I, but Fruela I who was said to have launched such attacks! Now, if al-Razi had access to historical material on early Asturias and if his ascribing those campaigns to Alfonso I is at odds with the Asturian chronicles, then this may add more to the suspicion that the royal chroniclers were not only shaping up their history at their greatest convenience, but also deactivating other existing, conflicting versions thereof.

${ }^{66}$ Ibn al-Athir, Tarij fi-Kamil, French partial translation in Fagnan (1898), p. 104.

${ }^{67}$ Ibn Khaldun, Kitab al-Ibar, French translation in Dozy, R. (1965), I, pp. 92-116. Al-Qalqashandi, Subh al-Asa fi Kitab al-Insa, Spanish translation Seco de Lucena (1975) 81. The text in al-Qalqashandi depends closely on Ibn Khaldun. It is typical of this branch to include the reference to Abd al-Rahman's early troubles and to add Castile (sic) to the list of seized cities. This seems to represent a later tradition, while Ibn al-Athir, whose quotations of Ibn Hayyan are very reliable, seems to be as close as we can get nowadays to the original passage by al-Razi. I am indebted to Luis Molina for his comments on this respect.

68 The date for Alfonso's death is wrong in Ibn Khaldun, but sound in Ibn alAthir. We cannot ascertain whether the sentence in Ibn Khaldun's version connecting the whole episode to Abd al-Rahman I's troubled early years belonged to al-Razi or was interpolated, but at any rate it fits much better Fruela's reign than Alfonso's. 
To this we can add the evidence from the Historia Silense. This is a twelfth-century Latin chronicle written-probably in León-in praise of King Alfonso VI (1065-1109). ${ }^{69}$ The author put together a number of different, not necessarily compatible materials. As he was trying to narrate history following a genealogical programme, his discourse did not always keep to chronological order. Among these inconsistencies, we find two relevant passages. In $H S, 26$, the author followed the Oventesis in presenting the king as descended from Reccared, but he did not fail to note Alfonso's marriage to Pelagius's daughter. He also abbreviated and modified the passage in the royal chronicles about the attacks to the plainlands:

Together with his brother Fruela, he often led the army in campaign and took by force many of the cities oppressed by the barbarians; he removed from the churches the abominable name of Muhammad and had them consecrated in the name of Christ. ${ }^{70}$

Then, in HS, 32, when dealing with count Fruela, Alfonso's brother, he turned back to speak of the same period, and assigned to him a passage in which all the familiar ingredients are present:

Fruela indeed, the generous offspring of Peter, the duke of the Cantabri, together with Alfonso the Catholic, his brother and his fellow in reigning, he often took arms against the barbarians, and from the coastal fringes of Asturias and Galicia down to the river Duero he seized and removed from their hands every existing city and castle and, after eliminating the Ysmaelites by the sword, he returned them to the Christians' rightful possession. ${ }^{71}$

In this, as in so many other elements, the Historia Silense, by exaggerating the discourse line of the Chronicle of Alfonso III, seems to be exposing the latter's methods. The crucial point here is the confusion between the two Fruelas: respectively, Alfonso I's brother and his son King Fruela I. It seems plausible that the campaigns into the plains were originally attributed to Fruela I. Then the royal

69 See Gil (1995) 10-14.

70 HS, 26: . . . exercitum cum Froyla fratre sepius movens, quamplurimas a barbaris oppressas civitates bellando cepit, ecclesias nefando Mahometis nomine remoto in nomine Christi consecrari fecit. . .

${ }^{71}$ HS, 32: Igitur Froyla, Petri Cantabrorum patricii ducis generosa proles, cum germano fratre Adefonso catholico atque regni socio arma contra barbaros crebro arripiens, ab ipsis maritimis finbriis Asturie et Gallecie usque ad Dorium flumen, omnes civitates et castella que infra conti-

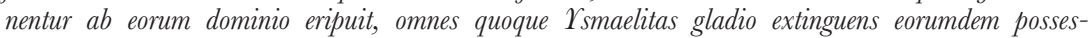
siones iuri christianorum mancipavit. 
chroniclers moved the whole episode one generation back, and assigned it to Alfonso together with his brother Fruela. Thanks to this resource - to shift from one Fruela to another - they managed to provide an acceptable transition from a long-established version to a new one. Not only this; they also poured military glory on a rather obscure character, but one who played a great role in the kingdom's dynastic evolution, as I will suggest in the next section.

But, before moving on to dynastic affairs, one more question needs to be asked. As we have seen, Alfonso I's image as a victorious warrior king has established itself firmly in Asturias in the 880s. Yet, only the two recensions of the Chronicle of Alfonso III engaged in the delicate task of putting together new and existing pieces of historical discourse, in order to create a narration that would support the notion that the whole Duero basin was emptied by Alfonso I of all its dwellers so that the ninth-century kings might justly recover it. Now, how was such a strange idea constructed?

True, the 'deserted place' was an appealing motif to clerical minds, to be found nearly everywhere in medieval hagiography. ${ }^{72}$ It was not innocent at all, though. References to deserted spaces are frequently found in accounts of the activities of Carolingian missionaries in Germany when what was at issue was the right to seize the lands that were under no one's recognized possession. It was not really necessary that there be no inhabitants there. Sometimes, the argument could be used by way of denial of local communities. For example, when Frankish monks succeeded in removing the relics of St. Vincent from Valencia, they justified themselves with the most unbelievable argument that those relics were held in a church with no parishoners. ${ }^{73}$ Exactly the same strategy was deployed in the eleventh-century when king Fernando I translated to Castile the relics of St. Vincent, St. Sabina and St. Cristeta from their martyrial shrine in Ávila, a city which lay beyond his kingdom's boundaries. ${ }^{74}$ The situation in the Duero basin is strongly reminiscent of the process by which the Anglo-Saxon missionaries seized control of the West Midlands by denying the previous existence of any British Christian communities there, although recent research shows traces of churches, organized

\footnotetext{
2 I am indebted to Julia Smith's stimulating comments on this point.

3 See García Moreno (1999) p. 321, n. 91.

74 Historia Silense, 94, ed. Pérez de Úrbel and González (1959) 197.
} 
communities and bishops. ${ }^{75}$ Likewise it seems increasingly plausible that the Duero dwellers had their own - albeit highly fragmentedecclesiastical structure, one which was denied in the process of imposing northernborn bishops, together with Asturian rule on them.

This may provide a general context of how the lack of population' could be argued to deny the locals and claim the right to control the land. Yet, the formulation of such a process in the Chronicles of Alfonso III takes the argument to its very extreme limits. Now, it is very interesting to compare Rot.-Ovet., 15 to the narration of Charles Martel's AD 737 campaign in Gothia (Septimania) in the Continuations to Fredegar's Chronicle:

Rot.-Ovet., 15: "Together with his brother Fruela, he led many fights against the Sarracens and he seized many cities once oppressed by them, that is, Lugo, Tuy, Oporto, (...), and all the castles with their vills and hamlets. Killing all the Arabs who occupied those cities, he took the Christians' with him to the homeland."

Fredegar's continuations: "And, having thus defeated their enemies, the Franks seized a great booty; after taking many captives, they depopulated the Gothic region. The most famous cities, Nîmes, Agde, Biterre, having their walls and defenses been torn down, they were set ablaze by him (Martel). He devastated their suburbs, and the castles of the region. Having dispersed the enemy's army, Christ reigning everywhere and with victory ornating his head, he safely returned to his region, in the land of the Franks, the soil of his principatum". ${ }^{76}$

Although clearly both passages are not verbally dependent, they are close enough in conception to suggest that the Frankish chronicle could have influenced the Asturians in building the whole notion of the depopulation of the Duero basin. Barbero and Vigil analysed very eloquently the many similarities that existed between the historical process of the eighth-century Duero basin, which was left void of all higher rule either Christian or Muslim - and that of contemporary Septimania. ${ }^{77}$ Here, Arab rule was only ephemerally established, and, until the region's eventual subjection to the Franks, its cities lived a separate existence, keeping to their Visigothic identity and legal traditions. But, as far as I know, no one hitherto has

\footnotetext{
75 Bassett (1992).

76 Ed. Krusch (1888) 177.

77 Barbero and Vigil (1978) 213 ff.
} 
noticed that the Asturian narration could be drawing on a previous Septimanian-related model. And we have seen above that historical conceptions developed under Carolingian rule in early ninth-century Septimania were quite influential in shaping the early Asturian historical consciousness. Stories of this kind about the Carolingian buildup in southern Gaul may have been known in late-ninth century Asturias to the extent that putting them to use about Alfonso I would make perfect sense.

Summing up, I think the chroniclers' strategy about Alfonso I's campaigns consisted of: a) taking a pre-existing account of the lands ruled by the Asturians - of uncertain origin and date - and ascribing it to Alfonso I's years; b) taking a pre-existing story about Fruela I's deeds and moving it back to Alfonso I; c) enhancing-after Carolingian models - the narration of the king's campaigns, in order to divide the Iberian northwest in a twofold territorial pattern: the northern mountainous lands populated with Christians and the Duero plainlands, totally void of all dwellers.

Complex and subtle as this scheme is, the need to argue for the plateau's depopulation would hardly account for the bother of making the whole discourse converge upon Alfonso I. In order to explain this, we need to move into the king's second set of attributes: kin relations.

\section{Alfonso I's Kin Relations}

The earlier generations of Asturian kingship were dominated by a number of regional powers of whom a dominating character could eventually claim superiority (Fig. 4). The absence of a formalized succession system, together with crossing marriage alliances between the main lineages would account for such a complex pattern, in which cognatic relations were equally important, if not more important than agnatic ones. Linear agnatic succession did not establish itself until the crucial period of Ramiro I's reign.

The reign of Alfonso II represents the first serious attempt to make sense of the earlier troubled period. History was narrated according to this anti-Visigothic, Carolingian-inspired scheme. Royal succession was also for the first time tightened up into a linear dynastic layout, even if one in which father-to-son succession was indeed rare. This is best illustrated by Alfonso II's 812 charter. Here, a vision of 
a God-favoured royal dynasty is presented in which, strikingly, kingship flows from Pelagius down to Alfonso II, totally regardless of other kings who actually ruled, such as Fávila or the whole of Alfonso I's branch!:

... Of which plague, by Your right hand - Christ - was Your servant Pelagius saved, who, having been elevated to princely power, fought victoriously, hit the enemy, and defended the Christian and Asturian people with sublime victory. Fruela, his daughter's very conspicuous son, stood decorated with the culmen of kingship. By him was founded in the place called Oviedo the church dedicated in Your sacred name ... ${ }^{78}$

If this is what could be considered as the early ninth-century 'official' version, then by the end of the century a new conception had set in, which largely contested it. The layout of royal succession and blood relationships in all three texts can be narrowed down to two alternating dynasties - those of Pelagius and Peter of Cantabriawhich interlinked precisely in the figure of Alfonso I, married to Pelagius's daughter.

Historians have frequently tried to conflate the data in all three chronicles into one single picture of Alfonso I's origin and relations, but this largely obscures the fact that the three texts differ significantly in crucial points. The main facts were established by the Albeldensis: "Alfonso I was the son of Peter, duke of Cantabria, and, as he came into Asturias, he took Pelagius's daughter, Bermesinda, by Pelagius's command". ${ }^{79}$ The Rotensis, instead, turned Alfonso's ancestry into 'royal', which in this context can only mean 'Visigothic': "Alfonso, son of Peter, duke of the Cantabri, of royal ancestry, came to Asturias. He married Pelagius's daughter, named Ermesind. With his father-inlaw he reached many victories ...". ${ }^{80}$ And perhaps showing a higher 'constitutional concern' - by contrast to the Albeldensis, which seems to have assumed that his royal marriage gave Alfonso I the throneit explained his royal accession by election: "After whose [Favila's] death, Alfonso was elected to the throne by the whole people". ${ }^{81}$

${ }^{78}$ Floriano (1949), doc. 24, 120-121. For the Latin text see above note 27. This is also in accordance to some versions of the Asturian regnal lists in which Aurelius is followed by Alfonso II, all other kings being written out; Gil (1985) 99.

${ }^{79}$ Alb. XV, 3. For the Latin text see above, note 43.

${ }^{80}$ Rot. 11: "Adefonsus filius Petri Cantabrorum ducis ex regni prosapiem Asturias aduenit. Filiam Pelagii nomen Ermesinda in coniungio accepit. Qui cum socero et postea victorias multas peregit..."

${ }_{81}^{81}$ Rot. 13 


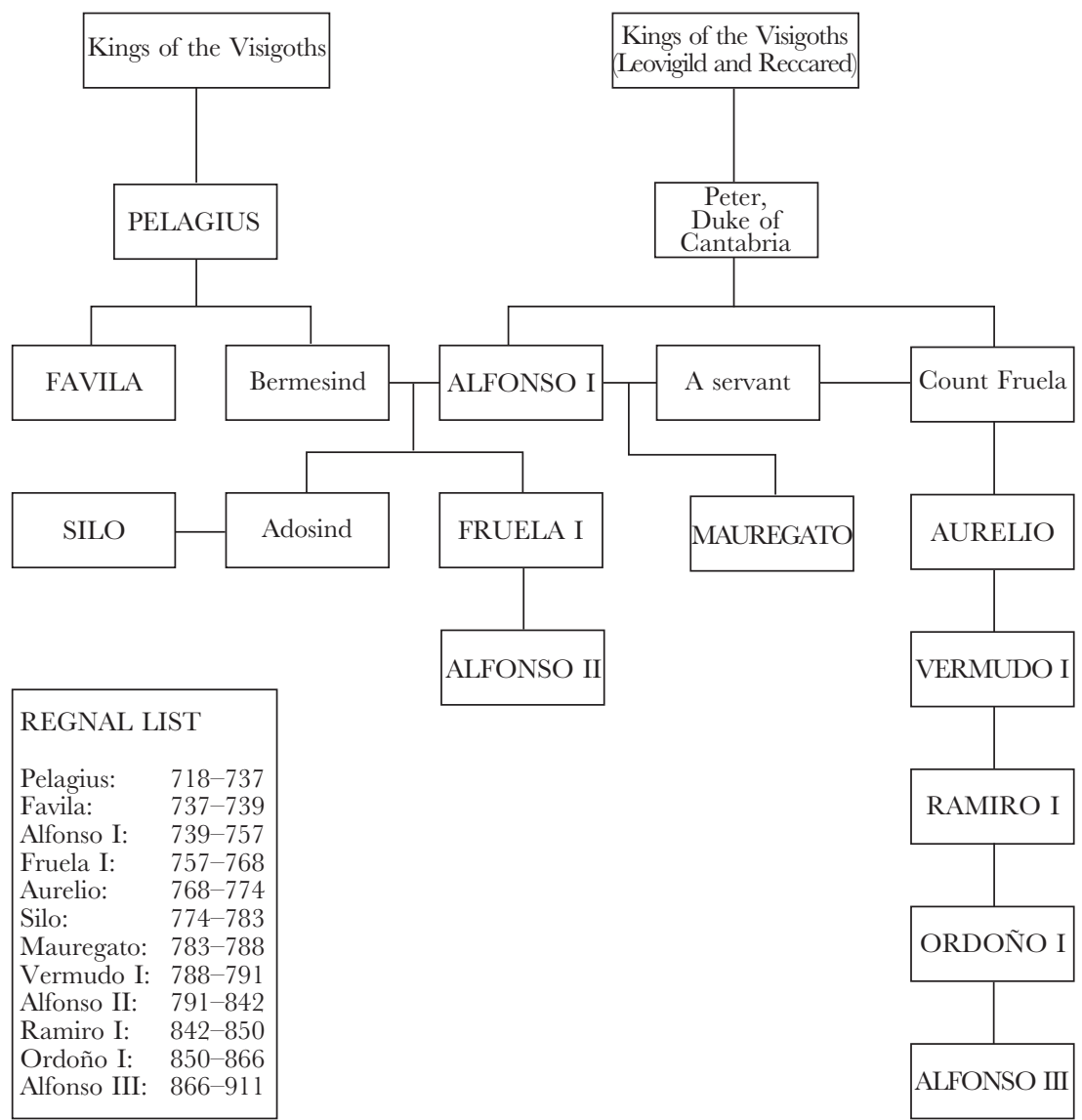

Fig. 4: The eighth- and ninth-century Asturian kings, according to the Ovetensis Chronicle.

The Ovetensis recension pointed more directly to dynastic matters. It not only condemned Pelagius's daughter to oblivion, but also sketched a more prestigious ancestry for Alfonso I: "He was the son of Duke Peter, born from the breed of kings Leovigild and Reccared. In the time of Egica and Witiza, he (Peter) was the army's principal". ${ }^{2}$ Amancio Isla has rightly noticed that, while the Rotensis takes issue in the debate on the ending of the Visigothic kingdom, by stressing the sins of Witiza and his family and enhancing the virtues of

${ }^{82}$ Ovet. 13. 
Roderic, ${ }^{83}$ the Ovetensis seems to turn the page on that matter, in an attempt to 'deactivate' the inherited notion that the Visigoths perished due to their own sins. ${ }^{84}$ In fact, the Ovetensis was more interested in stressing the continuity from the Gothic to the Asturian kingdom, which may well explain why in its account, the ancestry of Duke Peter of Cantabria is linked to the heyday of the Goths Leovigild and Reccared, not to their sorrowful decline. Moreover, in this version, Petrus, and Alfonso I after him, would have as good a title to kingship as Pelagius himself, if not better!

The dynastic aspects help in understanding many of the chroniclers' concerns and methods. They not only invented the depopulation of the Duero basin, but also took great pains to move most positive elements from Fruela I's reign to his father, Alfonso I's. Thus, despite having been powerful and victorious, Fruela's image is rather dominated by his anger, which led him to kill his own brother and later for himself to be killed in retribution. So, what was the point in making a positive figure out of Alfonso I, by denigrating his son Fruela? Alfonso III's chroniclers were evidently interested in enhancing their king's line. This, though, was a hard thing to do, due to the intricacies of eighth-century succession. Alfonso I's direct agnatic line just would not do. His son Fruela fathered Alfonso II, who died without an heir, and was succeeded - perhaps after a period in which both kings coincided conflictingly ${ }^{85}$ - by Ramiro I, the direct ascendent of Alfonso III. Moreover, Alfonso II was the archtype of Asturian pro-Carolingian policies, and the chroniclers had to make great efforts to write out all Frankish-scented elements and turn his more remarkable achievements into steps towards the restoration of the Visigothic kingdom. Besides, Alfonso II did not succeed Fruela I directly. King Aurelius (Fig. 4) represents a return to Alfonso I's family, but in his brother Count Fruela's collateral line. Then, Pelagius's kindred recovered the lead with Silo, but lost it to Mauregato - allegedly Alfonso I's son by a servant - and Vermudo, another son of Count Fruela's. Most importantly, despite Alfonso II's accession and long reign and despite Vermudo's being a cleric, this was the very point at which the late

${ }^{83}$ From the Carolingian period, this was the northern 'official' view, while Witiza's ascendancy had become a 'stamp of pride' among the southern Mozarabs by the mid-ninth century. See Menéndez Pidal (1956-1958).

${ }^{84}$ Isla (1998b) p. 309.

${ }^{85}$ Fernández Conde (1997). 
ninth-century ruling dynasty connected to their earlier ancestors.

The whole plot becomes apparent. The chroniclers needed to emphasize the ruling kindred's claims to power. In order to do so, they had to minimize Alfonso II's branch. Their claims had to concentrate on the generation before Fruela I, but their most direct kin node was not a strong one, since count Fruela never achieved kingship. Their strategy was to focus the prestige of victory on Alfonso, and then make his brother participate in those campaigns by association (which would also account for crediting to this branch the achievements that seemingly belonged to Fruela I): simul cumfratre suo Froilane multa aduersus Sarracenos prelia gessit atque plurimas ciuitates ab eis olim oppressas cepit. The brother-to-brother scheme, though, was too feeble. It needed to be reinforced by means of a prestigious common ancestor: Duke Peter of Cantabria. It is really shocking to see how much discussion there has been among historians about such a character and his implications for the late Visigothic and early Asturian history. Too little emphasis has been put on the crude fact that Duke Peter is never mentioned in any source at all before the late ninth-century chronicles. Do we not have every reason to be suspicious about his entering the historical narration in the very last scene, to provide Alfonso I and count Fruela with a common ancestor of Visigothic provenance? It seems too obvious that Duke Peter was the missing indispensable link for making Alfonso III's dynasty the direct descendents of Kings Leovigild and Reccared, the most glorious references in their cherished Visigothic past. Therefore, concentrating the crucial eighth-century developments on Alfonso I can be seen as the central piece in a wider scheme aiming to devise a glorious past for Alfonso III, and legitimate his policies.

\section{Alfonso I's Moral Qualities}

Alfonso III's complex political agenda can explain the need to make a great historical landmark of Alfonso I. His reign was narrated as momentuous and he made his way with honours to the after life. Alfonso I's high moral quality is stressed by all three texts, even if with different components. For the Albeldensis his being "loved by God and men" went together with his peaceful death. ${ }^{86}$ The Rotensis

\footnotetext{
86 Alb. XV, 3.
} 
went a lot further, by noting down his religious virtues, followed by a death-bed miracle:

He was a great man. He was loved by God and men. He built many churches. He reigned for eighteen years. He died due to natural causes. And I will not silence a miracle which I know for certain to have occurred. For when his soul departed in the silence of the night, and the palace guards were diligently watching over his body, suddenly the voices of angels were heard in the air by those present, singing: 'See how the just is taken and no one notices; and just men are taken and no heart realizes. From the face of iniquity the just is taken; he will be in peace in his grave' You must know that this is all true, do not think it fabulous: I would rather keep silent than speak falsities. ${ }^{87}$

This was reproduced by the Ovetensis recension almost verbatim. Only the first lines were changed for the greater emphasis:

So, the aforesaid Alfonso was indeed magnanimous. Without any offence to God or the Church, he led a life worthy of imitation. He built or restored many temples. He reigned for 18 years. He happily ended his life in peace. And I will not silence this wonderful miracle . . ${ }^{88}$

By this means, Alfonso I became one among only three eighthcentury kings to have been marked by God with a miracle, and a relevant one indeed, since the angelic choir on his death-bed clearly implied his being summoned to heaven and sanctity.

${ }^{87}$ Rot. 14-15: "Hic vir magnus fuit. Deo et ominibus amavilis extitit. Baselicas multas fecit. Vixit in regno a. XVIII. Morte propria discessit. Nec hoc miraculum silebo, quod uerius factum esse cognosco. Quumque spiritum emisisset in tempeste noctis silentia cum offciis palatinis corpus custodissent, subito in aera auditur a cunctis uox angelorum psallentium: "Ecce quomodo tollitur iustus et nemo considerat; et uiri iusti tolluntur et nemo percipit corde. A facie iniquitatis sublatus est iustus; erit in pace sepultura eius". Hoc uerum esse cognoscite et nec fabulosum putetis: alioquin tacere magis quam falsa promere maluissem.

88 Ovet. 14-15. "Itaque supra dictus Adefonsus admodum magnanimis fuit. Sine offensione erga Deum et eclesiam uitam merito imitabilem duxit. Baselicas plures construxit uel instaurabit. Regnauit annos XVIII. Uitam feliciter in pace finiuit. Nec hoc stupendum miraculum pretermittendum est, quod hora discessionis eius certissime actum est. Nam quum spiritum emisisset in tempeste noctis silentia et excubie palatine diligentissime corpus illius obseruassent, subito in aera auditur a cunctis excubantibus uox angelorum psallentium: "Ecce quomodo tollitur iustus et nemo considerat; et uiri iusti tolluntur et nemo precipit corde. A facie iniquitatis sublatus est iustus; erit in pace sepultura eius". Hoc uerum esse prorsus cognoscite nec fabulosum dictum putetis: alio quin tacere magis eligerem quam falsa promere maluissem. 


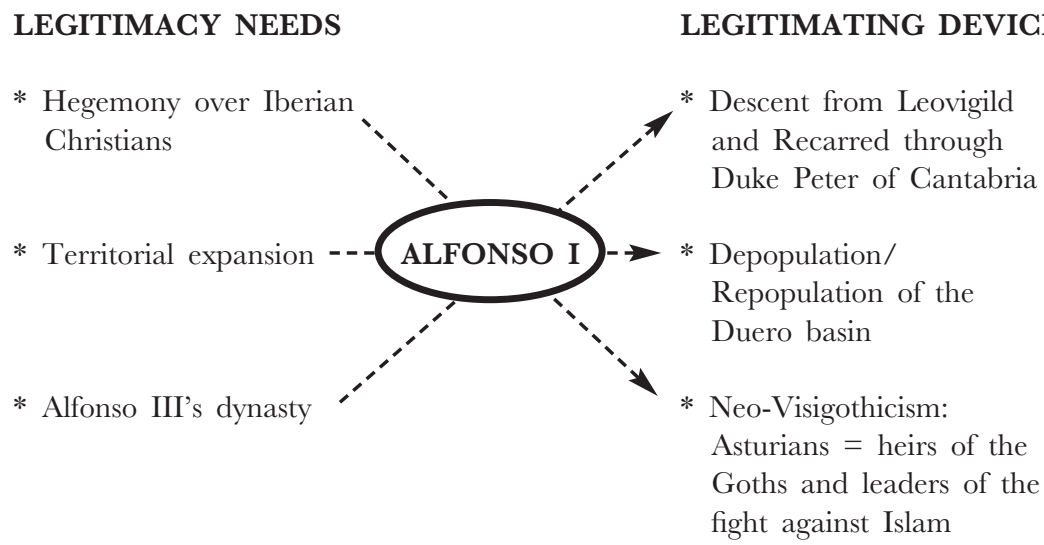

Fig. 5: Alfonso I as a discourse node.

\section{Conclusion: Alfonso I as a Discourse Node}

I have tried to show that the image of Alfonso I in the late-ninth century chronicles largely resulted from a subtle, systematic manipulation of the historical and narrative material. This was aimed to 'deactivate' existing undesired visions of the eighth-century Asturian history, and replace them with a new one which fulfilled the legitimation needs of Alfonso III's time.

The result was that Alfonso I became the main figure in mideighth-century Asturian history. I have presented the many reasons why we can suspect that he did not actually play such a paramount role. The fact that he is said to have done so in the chronicles is largely due to his being what I would call a 'discourse node'. As shown in Fig. 5, Alfonso I was a point crossed by a number of discourse lines, all of which were of essential importance to Alfonso III's policies. In a dynastic dimension, he was the key element giving prestige to Alfonso III's dynastic branch, by means of his association to count Fruela, and his allegedly descending from Peter of Cantabria and the Visigothic kings. This helped to stress the whole notion of neo-gothicism, which ultimately was, as seen before, an ideology of Iberian-wide hegemony. In the meantime, most traces of a previous Carolingian-driven political growth were carefully erased. Moreover, the narration about the lands he populated and those which he devastated entailed a subtle discourse justifying the status of the kingdom's two main territorial components, and legitimating the Asturian take-over of the plateau. 
All of those discourse lines cut across the figure of Alfonso I. Rather than a real king, he can be seen as an essential tool for discourse construction which went much further than just open statements. The multilayered nature of the chronicles' discourse needs to be emphasized. The texts can be read at several different levels, and some of their arguments can only work properly if they flow very unexplicitly. While some of the chroniclers' concerns - such as the Asturian 'gothicness' - were spoken out loud, others - such as their dynastic allegiance - remained largely hidden, and can only be exposed by carefully deconstructing the ways in which they manipulated, and added to their inherited historical material. The different degree of internal consistency in the three texts is essential in understanding the Ovetensis' most programmatic strategies.

Inevitably, another consequence of the kind of analysis I am proposing, and one I cannot deal properly with in this context, is that it casts considerabble doubt on how much we can learn about the Asturian eighth-century from those texts. The easy, short answer would perhaps be 'nothing', but I think this can be modified by a subtle consideration of the discourses the chroniclers were trying to deactivate. Certainly, more investigation about the Asturian elements in Arabic texts, and how close they can be to al-Razi's original work would also be of great help. Instead I think that it is no longer a valid approach to take the chronicles at face value, out of context, or to conflate the narrations in the three texts into a single discourse.

Surely, our most outstanding sources for the Asturian mid-eighthcentury history say very little indeed about the eighth century while they tell a great deal about the late-ninth and their authors' political and cultural milieu. Also about the way in which their historical conceptions were a part of their political actions. When looking at the intricate web of meanings attached to him, we can see that Alfonso I probably never existed as we read in the texts, but whoever he was and whatever he did, his descendent Alfonso III had a taylor-cut ancestor made out of him, of whom to be very proud.

\section{Acknowledgments}

I started working on this paper while being on a post-doctoral research leave at University College London, funded by the Spanish Ministerio de Educación y Cultura. A preliminary version was delivered in a 
Seminar at the University of St. Andrews within the St. AndrewsMadrid 2000-2001 Acción Integrada (see above Introduction). The final version was developed in the framework of a research project funded by the Spanish Ministerio de Ciencia y Tecnología, directed at the Departamento de Historia Medieval of the Instituto de Historia (Madrid, CSIC) by Dr. Isabel Alfonso in 2000-2002.

I am indebted to all those who have contributed with their comments to improve this paper, particularly the members of the St. Andrews-Madrid group, as well as Dr. Amancio Isla (Universidad Rovira i Virgili, Tarragona), Dr. Maribel Fierro (Instituto de Filología, CSIC, Madrid), Dr. Luis Molina (Instituto de Estudios Árabes, CSIC, Granada), Jorge Manzano, Teri Nava-Vaugh (Stanford University, California) and Hugh Kennedy (St. Andrews University). Needless to say I am the only one to blame for all possible shortcomings.

\section{Bibliography}

Acién Almansa, M. (1994) Entre el feudalismo y el Islam. Umar Ibn Hafsun en los historiadores, en las fuentes y en la historia, Jaén.

Aguadé, J. (1991) Abd al-Malik b. Habib (m. 238/859). Kitab al-Tarij (La Historia) (Madrid: 1991).

Azkárate Garai-Olaun, A. (1993) "Francos, Aquitanos y Vascones. Testimonios arqueológicos al sur de los Pirineos", Archivo Español de Arqueología 66 (1993) 149-176.

Azkárate Garai-Olaun, A.; Quirós Castillo, J.A. (2001) "Arquitectura doméstica altomedieval en la Península Ibérica", Archeologia Medievale, 28 (2001) 25-60.

Barbero, A.; Vigil, M. (1978) La formación del feudalismo en la Península Ibérica (Barcelona: 1978).

Bassett, S.R. (1992) "Church and diocese in the West Midlands: the transition from British to Anglo-Saxon control", in Pastoral Care before the Parish, ed. J. Blair and R. Sharpe (Leicester: 1992) 13-40.

Cavadini, J.C. (1993) The Last Christology of the West: Adoptionism in Spain and Gaul, 785-820 (Philadelphia: 1993).

Castellanos, S.; Martín Viso, I. (forthcoming) "The local articulation of central power in the north of the Iberian peninsula, 500-1000", Early Medieval Europe.

Collins, R. (1989) The Arab Conquest of Spain, 710-797 (Oxford: 1989).

- (1998) Charlemagne (London: 1998).

D'Abadal i de Vinyals, R. (1949) La batalla del adopcionismo y la desintegración de la Iglesia Visigoda, (Barcelona: 1949).

Dacosta Martínez, A. (1992) "Notas sobre las crónicas ovetenses del siglo IX. Pelayo y el sistema sucesorio en el caudillaje asturiano", Studia Historica. Historia Medieval, 10, (1992) 9-46.

David, P. (1947) Études historiques sur la Galice et le Portugal du VI e au XI siècles, (Lisbon: 1947).

Díaz y Díaz, M.C. (1970) "La historiografía hispana desde la invasión árabe hasta el año 1000", in La storiografía altomedievale. XVII Settimane di Studio del Centro Italiano di Studi sull'Alto Medioevo, (Spoleto: 1970) I, 313-343. 
(1976) "Los himnos en honor de Santiago en la liturgia hispánica", in Díaz y Díaz, M.C. De Isidoro al siglo XI. Ocho estudios sobre la vida literaria peninsular, (Barcelona: 1976) 235-288.

— (1983) Códices visigóticos en la monarquía leonesa (León: 1983).

Dozy, R (1965) Recherches sur l'histoire et la literature de l'Espagne pendant le Moyen Age (Amsterdam: 1965).

Escalona, J. (1991) "Algunos problemas relativos a la génesis de las estructuras territoriales de la Castilla altomedieval", in Burgos en la Alta Edad Media (Burgos: 1991) 489-506.

- (2000a) Transformaciones sociales y organización del espacio en el alfoz de Lara en la Alta Edad Media, PhD dissertation, CD-ROM ed. (Madrid: 2000).

- (2000b) "Paisaje, asentamiento y Edad Media: reflexiones sobre dos estudios recientes", Historia Agraria, 20 (2000) 227-244.

— _ (2001) 'De 'señores y campesinos' a 'comunidades y poderes feudales'. Elementos para definir la articulación entre territorio y clases sociales en la Alta Edad Media castellana" in Comunidades locales y poderes feudales en la Edad Media, coord. I. Álvarez Borge (Logroño: 2001) 115-155.

- (2002) Sociedad y Territorio en la Alta Edad Media Castellana. La formacion del alfoz de Lara, British Archaeological Reports. International Series 1079 (Oxford: 2002).

- (forthcoming) "Comunidades, territorios y poder condal en la Castilla del Duero en el siglo X", Studia Historica. Historia Medieval.

Estepa, C. (1992) "Configuración y primera expansión del reino astur. Siglos VIII y IX", in De Constantino a Carlomagno. Disidentes, heterodoxos y marginados, ed. F.J. Lomas and F. Devís (Cádiz: 1992) 179-195.

(2002) "El poder regio y los territorios", in La época de la Monarquía Asturiana. Actas del Simposio celebrado en Covadonga (8-10 de octubre de 2001) (Oviedo: 2002) 451-467.

Fagnan, E. (1898) Annales du Maghreb et de l'Espagne (Argen: 1898).

Fernández Conde, F.J. (1971) El Libro de los Testamentos de la Catedral de Oviedo (Rome: 1971).

_ (2000) La religiosidad medieval en España. I. Alta Edad Media (s. VII-X), Oviedo.

(1997) "Relaciones politicas y culturales de Alfonso II el Casto", in Historia social, pensamiento historiográfico y Edad Media. Homenaje al Prof. Abilio Barbero de Aguilera, ed. M.I. Loring García (Madrid: 1997) 597-611.

Fernández Conde, F.J.; Suárez, M.J.; Gutiérrez, J.A. (1997) "A transición en Asturias Aproximación historiográfica e percepción do territorio astur na Alta Idade Media", in Galicia fai dous mil anos: o feito diferencial galego, coord. G. Pereira Menaut (Santiago de Compostela: 1997) I, 391-412.

Fierro, M. (1998) "Four questions in connection with Ibn Hafsun", in The Formation of Al-Andalus. I: History and Society, ed. M. Marín (Aldershot: 1998) pp. 291-328.

Floriano Cumbreño, A.G. (1949) Diplomática española del período astur (718-910) (Oviedo: 1949).

Floriano Llorente, P. (1975) "El testamento de Alfonso II (Estudio paleográfico y diplomático)", Boletín del Instituto de Estudios Asturianos, 86 (1975) 593-617.

Fouracre, P. (2000) The Age of Charles Martel (Harlow: 2000).

García de Cortázar, J.A. (1997) "El espacio castellano y alavés en la época de Alfonso II el Casto", Cuadernos de Historia de España 74 (1997) 101-120.

García Moreno, L.A. (1975) "Sobre un nuevo ejemplar del Laterculus Regum Visigothorum", Analecta Sacra Tarraconensia 47 (1975) 8-19.

(1999) "Spanish Gothic consciousness among the Mozarabs in al-Andalus (VIII-Xth centuries)", in The Visigoths. Studies in Culture and Society, ed. A. Ferreiro (Leiden-Boston-Köln: 1999) 303-323.

Gil, J. (1978-1979) "Judíos y cristianos en España (S. VIII y IX)", Hispania Sacra, 31 (1978-1979) 9-88. 
(1995) "La historiografia tradicional" in La Cultura del Románico. Siglos XI al XIII. Letras. Religiosidad. Artes. Ciencia y Vida, coord. F. López Estrada (vol. XI of Historia de España Menéndez Pidal, dir. J.M. Jover Zamora) (Madrid: 1995) 3-24.

Gil, J.; Moralejo, J.L.; Ruiz de la Peña, J.I. (1985) Crónicas Asturianas (Oviedo: 1985). Gómez Moreno, M. (1932) "Las primeras crónicas de la Reconquista, el ciclo de Alfonso III", Boletín de la Real Academia de la Historia, 100 (1932) 562-623.

Holder-Egger, O. (1907) MGH. Scriptores Rerum Germanicarum, II (Hannover-Leipzig: 1911).

Huete Fudio, M. (1994) "Fuentes menores para el estudio de la historiografia latina de la Alta Edad Media hispánica (siglos VII-X)", Medievalismo, 4 (1994) 5-26.

Isla Frez, A. (1992) La sociedad gallega en la Alta Edad Media (Madrid: 1992).

(1998a) "El adopcionismo y las evoluciones religiosas y políticas en el Reino Astur", Hispania 200 (1998) 971-993.

- (1998b) "Los dos Vitizas. Pasado y presente en las crónicas asturianas", in Hidalgo, M.J., Pérez, D and Gervás, M.J.R. (eds.), "Romanización" y "Reconquista" en la Península Ibérica: nuevas perspectivas, ed. M.J. Hidalgo, D. Pérez and M.J.R. Gervás (Salamanca: 1998) 303-316.

Kurze, F. (1895) MGH. Scriptores rerum Germanicarum in usum scholarum (Hannover: 1895, repr. 1950).

Krusch, B. (1888) MGH. Scriptores Rerum Merowingicarum, II (Hannover: 1888).

Larrañaga, K. (1993) "El pasaje del pseudo-Fredegario sobre el dux Francio de Cantabria y otros indicios de naturaleza textual y onomástica sobre presencia franca tardoantigua al sur de los Pirineos", Archivo Español de Arqueología 66 (1993) $177-206$.

Levison, W. (1946) England and the Continent in the eighth century (Oxford: 1946).

Löfstedt, B. (1984) Beati et Eterii adversus Elipandum, Corpus Christianorum, Continuatio Medievalis, LIX (Turnhout: 1984).

Mállo Salgado, F. (1990) Zamora y los zamoranos en las fuentes arábigas medievales, Studia Zamorensia. Anejos, 2 (Zamora: 1990).

- (2002) "El Reino de Asturias desde la perspectiva de las fuentes árabes", in La época de la Monarquía Asturiana. Actas del Simposio celebrado en Covadonga (8-10 de octubre de 2001) (Oviedo: 2002) 229-249.

Makki, M.A.; Corriente, F. (2001) Ibn Hayyan. Crónica de los emires Alhakam I y Abdarrahman II entre los años 796 y 847 [Almuqtabis II-1] (Zaragoza: 2001).

Manzano Moreno, E. (1991) La frontera de Al-Andalus en época de los Omeyas (Madrid: 1991).

- (1997) "El 'medio cordobés' y la elaboración cronística en Al-Andalus bajo la dinastía de los Omeyas", in Historia social, pensamiento historiográfico y Edad Media. Homenaje al Prof. Abilio Barbero de Aguilera, ed. M.I. Loring García (Madrid: 1997) $59-85$.

_ (1991) "Señores y emires: familias aristocráticas y soberanía Omeya en AlAndalus", Cuadernos de Madinat al-Zahra, 3 (1991) 97-110.

Martin, G. (1997) Histoires de l'Espagne médiévale: Historiographie, geste, romancero, París.

Menéndez Pidal, R. (1956-1958) Floresta de leyendas heroicas españolas. Rodrigo el último Godo (Madrid: 1956-1958).

_ (1960) "Repoblación y tradición en la Cuenca del Duero", Enciclopedia Lingüistica Hispánica, 1 (Madrid: 1960) 29-57.

Pérez de Úrbel, J.; González Ruiz-Zorrilla, A. (1959) Historia silense (Madrid: 1959).

Pertz, G.H. (1826) MGH. Scriptores, I (Hannover: 1826).

Prelog, J. (1980) Die Chronik Alfons III. Untersuchungen und kritische Edition der vier Redaktionen, (Frankfurt-Bern-Cirencester: 1980).

Romero-Pose, G. (1985) Beato de Liébana (Sancti beati a Liebana Comentarius in Apocalipsin) (Rome: 1985).

Sánchez-Albornoz, C. (1966) Despoblación y Repoblación en el Valle del Duero (Buenos Aires: 1966). 
(1967a) “Una crónica asturiana perdida?”, in Sánchez-Albornoz, C., Investigaciones sobre historiografia hispana medieval (siglos VIII al XII) (Buenos Aires: 1967) 111-160.

(1967b) "El relato de las campañas de Alfonso I", in Sánchez-Albornoz, C., Investigaciones sobre historiografia hispana medieval (siglos VIII al XII) (Buenos Aires: 1967) 203-214.

- (1967c) "La crónica del moro Rasis y la Continuatio Hispana", in SánchezAlbornoz, C., Investigaciones sobre historiografia hispana medieval (siglos VIII al XII) (Buenos Aires: 1967) 267-302.

Seco de Lucena, L. (1975) Al Qalqasandi. Subh al-Asa fi kitabat al-Insa (Valencia: 1975).

Suárez Álvarez, M.J. (2002) "La Monarquía Asturiana. Nuevas perspectivas de interpretación", in La época de la Monarquía Asturiana. Actas del Simposio celebrado en Covadonga (8-10 de octubre de 2001) (Oviedo: 2002) 203-227.

Thorpe, L. (1969) Einhard and Notker the Stammerer. Two lives of Charlemagne (Harmondsworth: 1969).

Torrente Fernández, I. (1997) "Sedes regias de la monarquia asturiana", in Historia social, pensamiento historiográfico y Edad Media. Homenaje al Prof. Abilio Barbero de Aguilera, ed. M.I. Loring García (Madrid: 1997) 575-591.

- (2002) "Goticismo astur e ideología política", in La época de la Monarquía Asturiana. Actas del Simposio celebrado en Covadonga (8-10 de octubre de 2001) (Oviedo: 2002) 295-315.

Wasserstein, D.J. (2002) "Inventing tradition and constructing identity: the genealogy of Umar ibn Hafsun between Christianity and Islam", Al-Qantara, 23/2 (2002).

Wolf, K.B. (1988) Christian Martyrs in Muslim Spain, (Cambridge: 1988)

(1990) Conquerors and chroniclers of Early Medieval Spain (Liverpool: 1990). 